\title{
Application of the emulsion explosives in the tunnels construction
}

\author{
Oleh Khomenko ${ }^{1 *}$, Maksym Kononenko ${ }^{1}$, Inna Myronova $^{2}$, and Mykola Savchenko ${ }^{3}$ \\ ${ }^{1}$ Dnipro University of Technology, Department of Underground Mining, 19 Yavornytskoho, \\ 49005 Dnipro, Ukraine \\ ${ }^{2}$ Dnipro University of Technology, Department of the Ecology and Environmental Protection \\ Technologies, 19 Yavornytskoho, 49005 Dnipro, Ukraine \\ ${ }^{3}$ Ltd. IST-FORT, 4 Kaplunivsky Alley, 61000, Kharkiv, Ukraine
}

\begin{abstract}
The analysis has been made of the technical parameters of the existing passport for drilling and blasting operations (DBO) in terms of compliance with labour safety requirements and scientific-technical standards. The methodology for constructing the DBO passport has been developed, which takes into account the areas of blast-hole groups and the properties of emulsion explosives. The type of the cut has been analysed, modelled and accepted for use, which corresponds to the conditions of tunnelling as much as possible. The zones of deformation and fracturing in the massif around blast-hole charges have been simulated. The level of decrease in the hazard index for atmospheric air has been set when using the emulsion explosive Ukrainit-PP instead of TNT-containing charge Ammonite No.6 ZhV.
\end{abstract}

\section{Introduction}

The construction of the Metro (Dnipro, Ukraine) began in 1981, and the first stations were put into operation in 1995. For today, most of the first metro line has been working, which connects the central railway station with the western city part. The length of the line is $7.8 \mathrm{~km}$, and the time of one-way trip is 15 minutes. There are 6 stations in Dnipro today: "Pokrovska", "Prospekt Svobody", "Zavodska", "Metalurhiv", "Mashynobudivnykiv", and "Vokzalna". Currently, 3 new stations are being built from the central railway station ("Vokzalna" station) in the direction of the city center: "Teatralna", "Tsentralna", and "Muzeina". The length of the second construction stage is $4 \mathrm{~km}$, and time of the trip to the railway station is 7 minutes. "Muzeina" station will be the deepest one, which will be built at a depth of 67 meters $[1,2]$.

The alluvial soils of the Dnipro city are composed of loess and clayish soil, and in case of disrupting the natural groundwater balance, they are prone to uncontrollable quicksand formation $[3,4]$. Freezing of water-flooded rocks has not been used for a long time due to the lack of working equipment. To use the technologies of jet grouting, constructing the cement columns and piles in the rocks, and other modern methods of fastening and cementing the unstable massifs in Ukraine, there is not sufficient experience and

\footnotetext{
* Corresponding author: rudana.in.ua@gmail.com
} 
appropriate equipment $[5,6]$. In this connection, the work is performed by foreign contractors who have new technologies, modern equipment and trained staff [7].

The initial project of the metro construction, developed in the 70s of the last century, has been changed by $90 \%$, since it was focused on driving the shafts with the use of the freezing method. The main technological changes have affected the number and method of driving the vertical shafts, as well as their diameter and method of fastening [8]. The initial $6 \mathrm{~m}$ diameter of the shafts did not give an ability to use the excavating machinery when driving. Therefore, the diameter has been increased to $12 \mathrm{~m}$. The Austrian technology was used to build a monolithic shaft fastening with the help of cement columns. In the future, it will be possible to operate shafts without special maintenance up to 100 years [9]. Currently, the vertical shafts are being driven with excavators equipped with hydraulic hammers. The driving rate does not exceed $0.35 \mathrm{~m}$ per day, and beginning with the mid2019, the tunnelling will be conducted by drilling and blasting method (Fig. 1) [10].

$a$

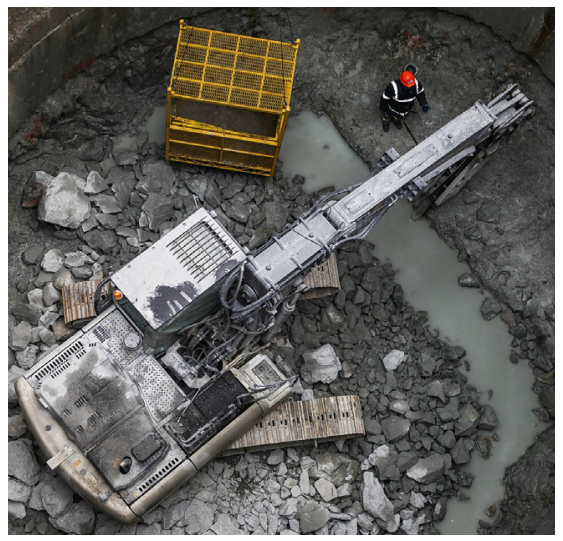

$b$

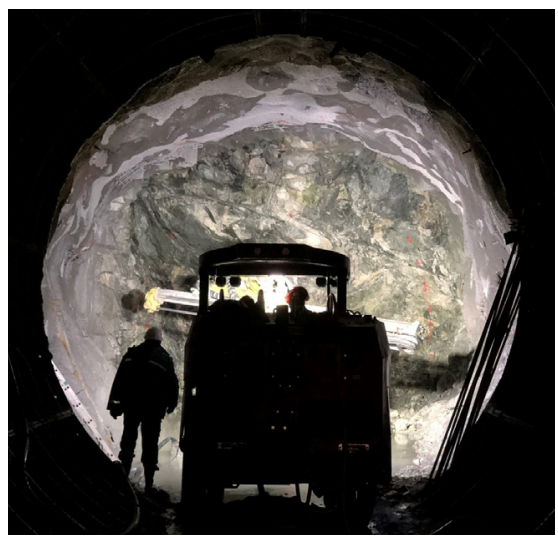

Fig. 1. Conducting the vertical shafts with a hydraulic hammer $(a)$, tunnelling by means of drilling and blasting method $(b)$.

The passport for drilling and blasting operations (DBO), according to which the metro tunnels were conducted in the Kiev and the Dnipro cities, was developed back in the 60s of the last century for the metro tunnels construction in the city of Moscow. The passport was intended to use the explosive compounds (hereinafter EC) containing TNT charge. Adjusting the designed parameters with the use of 3 trial explosions, made possible to use it more or less rationally in the conditions of the city of Dnipro. At the time of its creation, the Moscow passport was performed at a sufficiently high technical level, but for more than 50 years of its use, it ceased to comply with the modern labour safety requirements and scientific-technical standards. Besides, the use of TNT-containing explosives during tunnelling in the central part of the Dnipro city requires the satisfaction with the ecological standards for air pollution with harmful and dangerous gases [11].

\section{Analysis of performed research}

A detailed analysis of the technical parameters of the Moscow DBO passport has confirmed that its usage in modern conditions is contrary to the current normative legal documents, in particular the normative legal act NPAOP $0.00-1.66-13$ on labour protection. Also, the application of the square-contour diagram of blast-holes placement instead of contour one does not correspond to an ellipsoid shape of the tunnels section. Besides, the area of the cut 
has not been considered when calculating the total number of blast-holes in the driving place, as well as a type of the used cut has not been substantiated. The total number of calculation formulas is 13 , compared to the existing modern techniques for calculating the DBO passports containing about 30-50 design equations. Thus, the change in the geological conditions of conducting the mine workings or the blast-holes diameter, and more importantly, the transition to emulsion explosives requires the development of a new DBO passport that meets the modern scientific-technical standards.

The development and use of emulsion explosives, corresponding to different types of dynamite [12], dates back to the $60-70$ s of the 20 th century. The advantages of emulsion explosives are their low cost, complete charging mechanization, safety [13], the absence of hazardous individual explosives and environmental friendliness, due to the minimum content of harmful gases in the explosion products [14]. The use of TNT-containing explosives during drilling and blasting operations for tunnelling in the city of Dnipro will lead to increased levels of air pollution from explosion products. In the previously performed studies by means of the physical-chemical analysis and biological assessment [15] of the atmosphere air state, the degree of decrease has been determined in the concentration of harmful substances in the atmosphere during drilling and blasting operations with the use of Ukrainit emulsion explosive. And what is more, a decrease in technogenic impact on the atmosphere air and a decrease in ecological hazard index have been set [16]. The application of emulsion explosives in the construction of metro tunnels is difficult not only due to the absence of charging machines, but also due to the use of out-ofdate methods for calculating the DBO parameters, which are developed for TNT-containing explosives [17]. According to the study results of the change in the detonation velocity depending on the charge diameter [18], as well as the change in explosive properties over time [19], the high energy indicators have been determined compared with TNT-containing explosives. Therefore, there is a necessity to develop and implement a new technique for calculating the DBO parameters for the construction of tunnels in the city of Dnipro, which will consider not only the energy indicators of emulsion explosive [20], its environmental friendliness for atmosphere air [21], but also the safety of conducting the blasting operations [22].

\section{Research results}

A methodology for calculating the DBO passports was developed for the following mining and geological conditions of conducting the metro tunnels in the city of Dnipro. The characteristics of the blasting medium: granites, granite-gneisses, plagiogranites, finemedium-grained, of medium fracture density with rock hardness coefficient $f=12-15$. The rock density $\gamma=2.6 \mathrm{t} / \mathrm{m}^{3}$. The shape of mine working is ellipsoidal, the width of driving $B_{p r}-6.06 \mathrm{~m}$, the height of driving $H_{p r}-6.30 \mathrm{~m}$. The cross sectional area of tunnels in driving $S_{p r}=29.98$ sq.m. The depth of the blast-hole cluster $l_{s h}=1.6 \mathrm{~m}$. The diameter of the blast-hole $d_{s h}=0.042 \mathrm{~m} \mathrm{[23]}$.

The Ukrainit-PP emulsion explosive is used as the main explosive, for the manufacture of explosive cartridges - Ukrainit-P packaged explosive 32/250. The operational properties of Ukrainit-P 32/250: charge density $1.12-1.15 \mathrm{~g} / \mathrm{cm}^{3}$, heat of explosion $3700-3900 \mathrm{~kJ} / \mathrm{kg}$, detonation velocity $5000-5050 \mathrm{~m} / \mathrm{s}$, cartridge size $32 \mathrm{~mm}$, cartridge weight $250 \mathrm{~g}$. The operational properties of Ukrainit-PP: charge density $1.25 \mathrm{~g} / \mathrm{cm}^{3}$, heat of explosion $3100 \mathrm{~kJ} / \mathrm{kg}$, detonation velocity $5100 \mathrm{~m} / \mathrm{s}$.

The general methodology for calculating the DBO passport includes the following stages.

Total amount of explosive per driving place

$$
Q=q \cdot V
$$


where $q$ is specific consumption of explosive, $\mathrm{kg} / \mathrm{m}^{3} ; \mathrm{V}$ is the volume of rock in an exploding massif

$$
V=S_{p r} \cdot l_{s h}
$$

The specific consumption of explosives is determined by the formula of Professor N.M. Pokrovskiy [24]

$$
q=q_{1} \cdot e \cdot f_{1} \cdot k_{z a z h},
$$

where $q_{1}$ is normal specific consumption of explosive

$$
q_{1}=0.1 \cdot f
$$

where $e$ is coefficient of explosive performance in terms of explosion heat relative to the reference explosive of Ammonite No.6 ZhV

$$
e=\frac{4316}{Q_{\text {exp }}},
$$

where $Q_{\text {exp }}$ is the heat of explosion of the used explosive, $\mathrm{kJ} / \mathrm{kg} ; f_{1}$ is the coefficient taking into account the rock structure, which is equal to $0.8-2.0 ; k_{z a z h}$ is the rock clamping ratio, which is equal to $1.2-1.5$.

The efficiency of drilling and blasting operations mostly depends on the size of the cavity formed during explosion of the cut blast holes. Therefore, when conducting mine workings, depending on the properties and structure of the rocks, the position of the cut blast holes relative to the plane of the driving place and the principle of their operation, all types of cuts are divided into 2 groups: angling cuts (of detachable action) - cuts with angling blast-holes and parallel cuts and (of destructive action) - cuts with blast-holes, which are perpendicular to the plane of the driving place. The advantages of angling cuts are high blast efficiency in laminal and fractured rocks, simplicity of structural design, relatively low sensitivity to drilling accuracy. The disadvantages - the limited depth of the blast-holes, the difficulty of achieving the specified geometric elements, the need to adjust the DBO passport with a change in the cross sectional area of mine working, the relative small use of explosion energy for breaking the rocks, a large spray of rock. The advantages of parallel cuts are high blast efficiency in hard and monolithic rocks, high average pull of driving place per cycle, good breaking and bunching of debris. The disadvantages - high sensitivity to the accuracy of performance and its effect on the explosion indicators, reduced explosion indicators in rocks prone to plastic deformations.

Analysis of the advantages and disadvantages of cuts indicates that the parallel cuts are preferable [25]. The parallel cuts form blast-holes, drilled perpendicular to the plane of the driving place. This type of cuts, in some cases, is characterized by the presence of uncharged blast-holes, which form additional surfaces of outcropping. The parallel cuts are divided into slot, prismatic and spiral. The slot cuts may be horizontal or vertical and are formed by blasting a number of parallel blast-holes, arranged in one or two rows. The blastholes can be charged through one. The horizontal slot cut is applied to rocks with the location of fractures or layers that are close to horizontal with respect to the direction of conducting the mine working. The vertical slot cut is used for rocks with the location of fractures or layers that are close to vertical with respect to the direction of conducting the mine working. The prismatic cut is formed by blasting of $4-9$ contiguous parallel blastholes. Sometimes some blast-holes are not charged, or a blast-hole or well is drilled in the centre of the cut. They are used when conducting mine workings in the rocks of any hardness. The spiral cut is formed by blasting of 5-9 parallel blast-holes, arranged in a 
spiral. In the centre, as a rule, there is an uncharged blast-hole. Blasting is consecutive, one blast-hole at a time. It is applied to homogeneous rocks of medium hardness and hard rocks.

Having performed the analysis of parallel cuts for given mining and geological conditions, it is recommended to use two types of cuts - a slot cut with additional two blastholes from each side of the cut for expanding the cut part and a prismatic cut with an uncharged blast-hole in the centre.

The location of blast-holes in parallel cuts depends on the value of the resistance, which is taken relative to the outer blast hole [26]

$$
W_{o}=47 \cdot K_{t} \cdot K_{z} \cdot d_{z} \cdot \sqrt{\frac{\Delta}{\gamma \cdot e}},
$$

where $K_{t}$ is the coefficient of geological conditions depending on the category of rock fracturing, which is equal to $0.9-1.1 ; K_{z}$ is the clamping ratio, which is equal to 0.6 at $S_{p r}<4$ sq.m., $0.7-0.8$ at $S_{p r}=4-60$ sq.m. and 0.9 at $S_{p r}>60$ sq.m.; $d_{z}$ is the charge diameter, $\mathrm{m} ; \Delta$ is the charge density of explosive, $\mathrm{t} / \mathrm{m}^{3} ; \gamma$ is the rock density, $\mathrm{t} / \mathrm{m}^{3}$.

For the specified conditions and the achievement of the necessary pull of driving place per cycle, the area of the cut part of the driving place, bounded by auxiliary blast-holes, should be not less than 0.85 sq.m. After determining by the formula (6) the value of the resistance for the outer blast hole, the location should be established of the blast-holes in the slot and prismatic cuts.

The length of the cut slot

$$
b_{\text {shch }}=(1.1 \ldots 1.4) \cdot W_{o} .
$$

The minimum possible distance between the blast-holes, at which a slot is formed

$$
a=c \cdot d_{z} \cdot \sqrt{\frac{\Delta}{\gamma \cdot e}},
$$

where $c$ is coefficient, which depends on the group of rocks according to the building codes and standards.

After the calculations, a graphical disposition is performed of blast-holes in a slot cut with two additional blast-holes from both sides of the slot (Fig. 2).

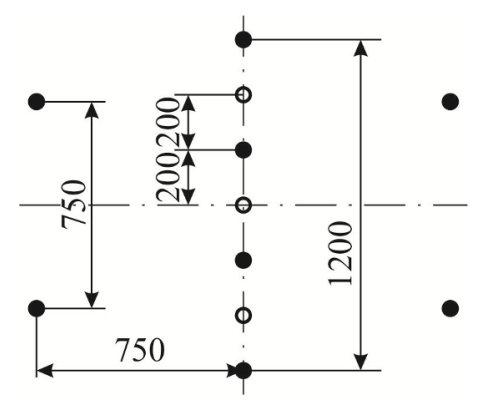

Fig. 2. The graphical disposition of blast-holes in a slot cut with two additional blast-holes from both sides of the slot.

With a prismatic cut, the blast-holes are located close to each other at a distance

$$
a=(0.2 \ldots 0.5) W_{o} .
$$


After calculations, a graphical disposition is performed of blast-holes in a prismatic cut with two auxiliary blast-holes (Fig. 3).

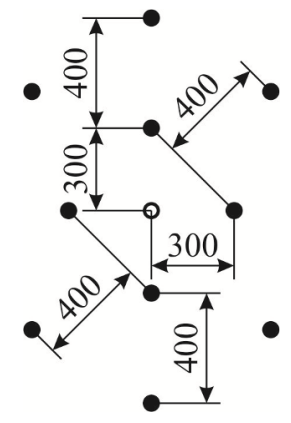

Fig. 3. The graphical disposition of blast-holes in a prismatic cut with two auxiliary blast-holes.

The simulation of processes occurring in the rock massif [27, 28], which demonstrates trustworthy results $[29,30]$ is widely used in underground mining. In this regard, to verify the appropriateness of arranging the blast-holes in the cut, as well as their work, an analytical simulation should be performed of the rock massif deformation around the blasthole charges using the 'SolidWorks Simulation' software, by means of which the displacements and deformations of the rock massif around the cut blast holes during their blasting can be determined. For this purpose, a life-sized model of massif should be created in the program with dimensions: height $-2.5 \mathrm{~m}$, width $-2.5 \mathrm{~m}$, length $-2.5 \mathrm{~m}$. The physical and mechanical properties of the model material correspond to the properties of the rocks in which the explosion will be produced. In the model, the blast-holes with a diameter of $42 \mathrm{~mm}$ and a length of $1.8 \mathrm{~m}$ are located identical to the diagrams in Fig. 3 and 4. In chargeable blast-holes, a pressure is created $(1390 \mathrm{MPa})$, which is equal to the pressure of the explosion products of the Ukrainit-PP explosive. As an example, consider the displacements and deformations of mine rocks around the blast-hole charges with a slot cut and prismatic cut (Fig. 4).
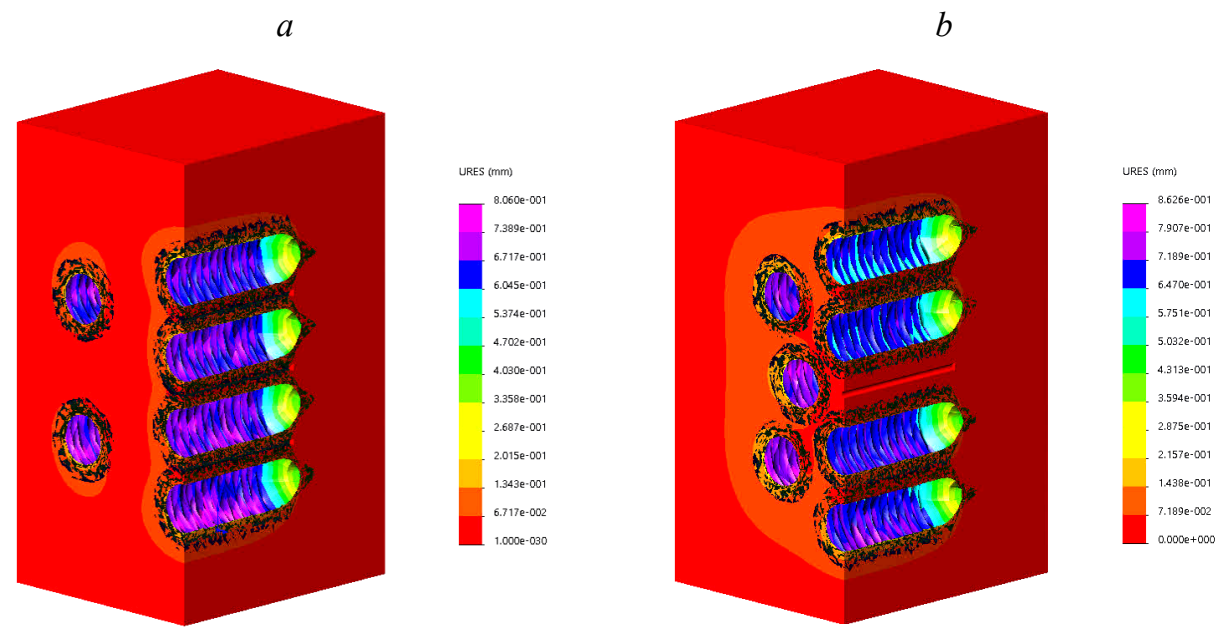

Fig. 4. The pattern of displacements and deformations in the massif when blasting the blast-hole charges in a slot cut (a) and prismatic cut (b). 
It can be seen from Fig. 4a, that when blasting the blast-hole charges in a slot cut with two additional blast-holes from both sides, only a vertical cut slot is formed. And around the additional blast-holes, only a zone of rocks fracturing is formed, which does not extend to the vertical slot, which will lead to the formation of oversize rock pieces. When blasting the blast-hole charges in the prismatic cut (Fig. 4b), a cut slot is formed, resembling an ellipse, and all the cut blast-holes form the zones of fractures formation around themselves, adjoining each other [31].

After conducting an analytical simulation of blasting the blast-hole charges in cuts, it can be stated that a prismatic cut is preferable. Because, when blasting its blast-hole charges, good breaking of rock occurs and a cut cavity is formed, which will follow the mine working shape. Then, consider the location of the rest blast-holes in the driving place of mine working. Based on the practical experience of compiling the DBO passports by the authors of works $[32,33]$, a methodology has been proposed for the blast-holes placement in the driving place of mine working. According to the methodology, the area of the driving place of mine working is divided into the areas of cut blast holes, outer blast holes, and contour blast-holes, in which the blast-holes will be located.

The area of the contour blast-holes

$$
S_{k}=S_{p r}-\pi \cdot \frac{B_{p r}-2 \cdot\left(\Delta_{o}+W_{k}\right)}{2} \cdot \frac{H_{p r}-2 \cdot\left(\Delta_{o}+W_{k}\right)}{2},
$$

where $\Delta_{o}$ is the distance from the mine working contour to the contour blast-holes, which is equal to $0.15-0.20 \mathrm{~m} ; W_{k}$ is the distance from the line of contour blast-holes to the exposed surface, which is formed by the outer blast holes and is equal to $0.5 W_{o}$.

The area of the driving place, which is occupied by the outer blast holes

$$
S_{o t b}=S_{p r}-\left(S_{v r}+S_{k}\right)
$$

where $S_{v r}$ is the cut area, sq.m.

Number of outer blast holes

$$
N_{o t b}=\frac{1.27 \cdot q \cdot S_{o t b}}{\Delta \cdot d^{2} \cdot k_{z a p}}
$$

where $\Delta$ is explosive density in a blast-hole or a cartridge, $\mathrm{kg} / \mathrm{m}^{3} ; d$ is the diameter of the blast-hole or explosive cartridge, $\mathrm{m} ; k_{z a p}$ is the charge ratio of the blast-hole, depending on the rock hardness is accepted to be $0.3-0.85$.

The area of the driving place, which corresponds to one outer blast hole

$$
S_{\text {otb.sh }}=\frac{S_{\text {otb }}}{N_{\text {otb }}} .
$$

The line of least resistance (LLR) of outer blast holes

$$
W_{\text {otb.sh }}=\sqrt{S_{\text {otb.sh }}} \text {. }
$$

The number of rows of outer blast holes from the cut to the area of the contour blastholes across the width of mine working

$$
N_{r . o t b}^{\text {shyr. }}=\frac{0.5 \cdot B_{p r}-\left(\Delta_{o}+0.5 \cdot W_{o}\right)-0.5 \cdot B_{v r}}{W_{\text {otb.sh }}},
$$

where $B_{v r}$ is the cut width, m. 
The number of rows of outer blast holes from the cut to the area of the contour blastholes across the width of mine working should be equal to a whole number.

The actual distance between the rows of outer blast holes from the cut to the area of the contour blast-holes across the width of mine working

$$
a_{r . o t b}^{\text {shyr. }}=\frac{0.5 \cdot B_{p r}-\left(\Delta_{o}+0.5 \cdot W_{o}\right)-0.5 \cdot B_{v r}}{N_{r . o t b}^{s h y r .}} .
$$

The number of rows of outer blast holes from the cut to the area of the contour blastholes throughout the height of mine working

$$
N_{r . o t b}^{v y s .}=\frac{0.5 \cdot H_{p r}-\left(\Delta_{o}+0.5 \cdot W_{o}\right)-0.5 \cdot H_{v r}}{W_{o t b . s h}},
$$

where $H_{v r}$ is the height of the cut, m.

The number of rows of outer blast holes from the cut to the area of the contour blastholes throughout the height of mine working should be equal to a whole number and correspond to the number of rows of outer blast holes from the cut to the area of the contour blast-holes across the width of mine working.

The actual distance between the rows of outer blast holes from the cut to the area of the contour blast-holes throughout the height of mine working

$$
a_{r . o t b}^{v y s .}=\frac{0.5 \cdot H_{p r}-\left(\Delta_{o}+0.5 \cdot W_{o}\right)-0.5 \cdot H_{v r}}{N_{r . o t b}^{v y s .}} .
$$

The distance between the outer blast holes in the row

$$
a_{\text {otb }}=m \cdot W_{\text {otb.sh }},
$$

where $m$ is burden-to-spacing ratio, which is equal to $0.8-1.3$, the lower value is accepted for hard rocks.

The number of outer blast holes in the $i$-th row

$$
N_{o t b . i}=\frac{L_{p i}}{a_{o t b}},
$$

where $L_{p i}$ is the length of the line of outer blast-holes location in the $i$-th row, $\mathrm{m}$.

The actual distance between the outer blast holes in the $i$-th row

$$
a_{o t b . i}=\frac{L_{p i}}{N_{o t b . i}} .
$$

The actual number of outer blast holes

$$
N_{o t b}=\sum_{1}^{i} N_{o t b . i} .
$$

The number of contour blast-holes

$$
N_{k}=\frac{P_{k}}{a_{k}},
$$

where $P_{k}$ is the perimeter of a line of the contour blast-holes row, m; $a_{k}$ is the distance between the contour blast-holes, which is equal to $0.75-0.95$ from $W_{o}$. 
The actual distance between the contour blast-holes

$$
a_{k}=\frac{P_{k}}{N_{k}} .
$$

The total number of blast-holes in the driving place of mine working

$$
N=N_{v r}+N_{o t b}+N_{k}
$$

where $N_{v r}$ is the number of cut blast holes, pcs.

Then, the total amount of explosive in the blast-holes is determined. The average charge value by one blast-hole

$$
Q_{s h}=\frac{Q}{N}
$$

The charge value of the cut blast hole

$$
Q_{v r}=(1.1 \ldots 1.2) \cdot Q_{s h} .
$$

The charge value of the outer blast hole

$$
Q_{o t b}=Q_{s h} .
$$

The charge value of the contour blast-hole from sides and roof

$$
Q_{k . b k}=(0.9 \ldots 0.95) \cdot Q_{s h} .
$$

The charge value of the contour blast-hole of the bottom

$$
Q_{k . p}=(1.0 \ldots 1.2) \cdot Q_{s h} .
$$

The actual explosive consumption per a driving place

$$
Q_{f}=N_{v r} \cdot Q_{v r}+N_{o t b} \cdot Q_{o t b}+N_{k . b k} \cdot Q_{k \cdot b k}+N_{k \cdot p} \cdot Q_{k \cdot p},
$$

where $N_{k . b k}$ is the number of contour blast-holes of the roof and sides of mine working, pcs.; $N_{k . p}$ is the number of contour blast-holes in the bottom of mine working, pcs.

Based on the calculated results of the distance between the blast-holes and the rows of blast-holes, the disposition of blast-holes is performed in the driving place of mine working (Fig. 5).

To test the DBO passport operation, an analytical simulation should be performed of the rock massif deformation around the blast-hole charges by means of the software product "SolidWorks Simulation". For this purpose, a life-sized model of massif should be created with dimensions: height $-10.0 \mathrm{~m}$, width $-10.0 \mathrm{~m}$, length $-4.0 \mathrm{~m}$. The physical and mechanical properties of the model material correspond to the properties of the rocks in which the mine working will be conducted. In the model, the blast-holes with a diameter of $42 \mathrm{~mm}$ are located according to the diagram of their disposition in the driving place of mine working, which is represented in Fig. 5. In chargeable blast-holes, a pressure is created $(1390 \mathrm{MPa})$, which is equal to the pressure of the explosion products of the Ukrainit-PP explosive. As an example, consider the displacements and deformations of mine rocks around the blast-hole charges after explosion (Fig. 6) [34]. 

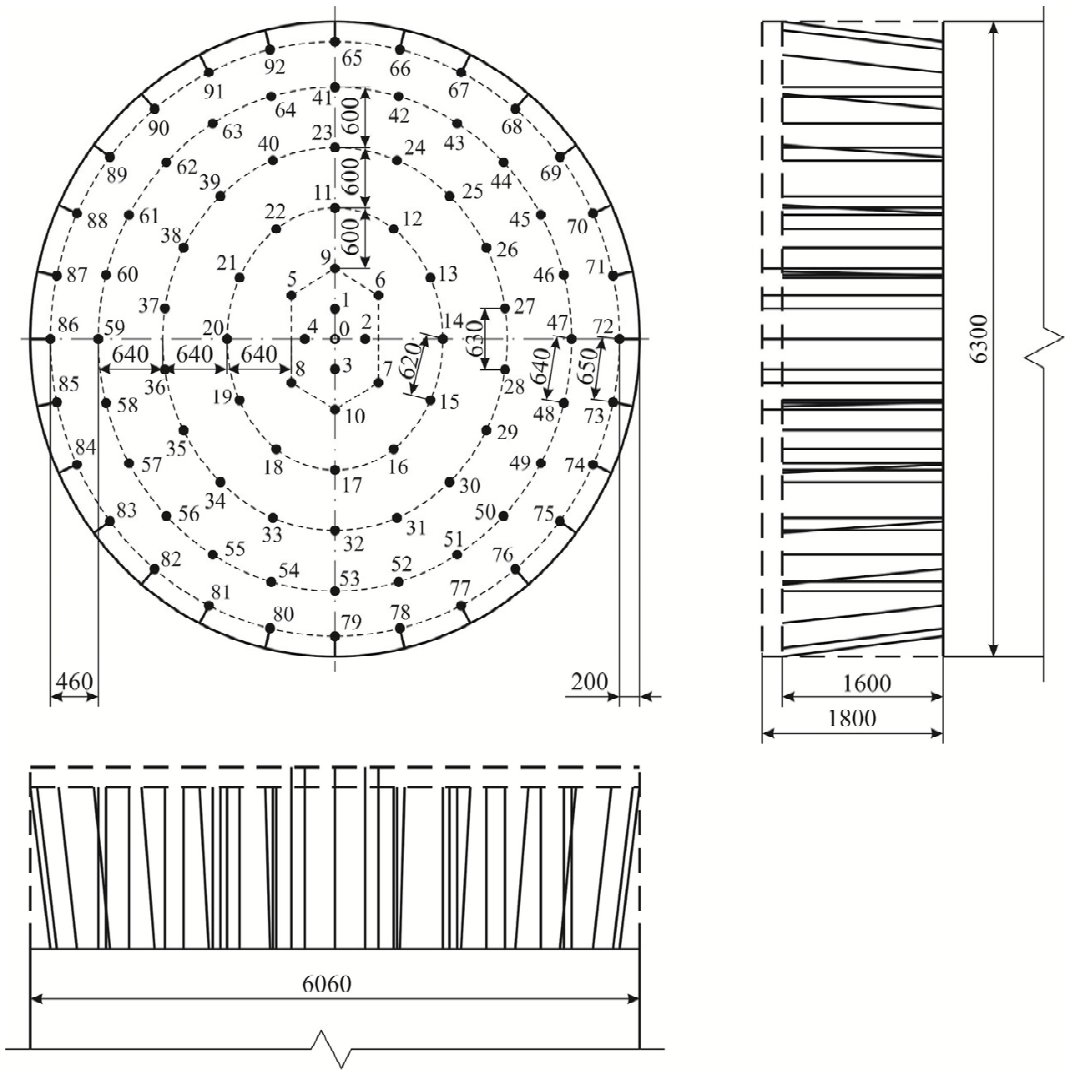

Fig. 5. The graphical disposition of blast-holes in the driving place of mine working.
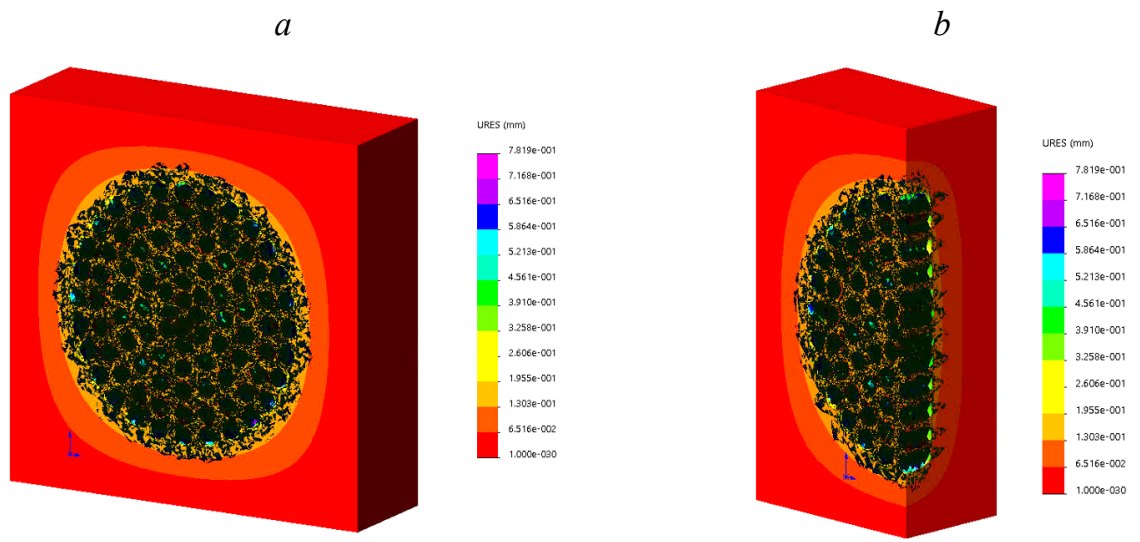

Fig. 6. The displacements and deformations of mine rock massif in the driving place (a) and along the blast-holes (b).

It can be seen from Fig. 6, that deformations and fractures formation of rocks around the blast-hole charges occur uniformly, which will lead to good breaking of rocks both in the plane of the driving place of mine working and along the length of the whole cluster of blast-holes. The extend of fractures beyond the design boundary of mine working will not exceed $0.2 \mathrm{~m}$, which may lead to an increase in section of mine working up to $3 \%$ [35]. 
According to the building codes and standards, when drilling and blasting method of conducting the mine workings, at a sectional area of more than 15 sq.m. in rocks with a hardness of $f=10-20$, an increase in the section up to $7 \%$ is permissible. Comparing and analysing the obtained results, it can be concluded that the DBO passport for conducting the tunnels has been calculated and compiled correctly [36].

The construction of tunnels and conducting the underground mining are related to the blasting operations. To date, when conducting the tunnels in Ukraine, the TNT-containing explosives Ammonite No. $6 \mathrm{ZhV}$ are used as standard explosives. After blasting operations in underground conditions, the polluted air through the shafts is released into the atmosphere. Depending on the shafts location, the released air stream has a negative impact on all the objects of the environment and the adjacent areas.

After blasting the explosives, the carbonic oxide and nitrogen oxides are emitted into the atmosphere, and their concentration was determined using the results of the study presented in the work [37]. The determination of the expected level of ecological hazard was made with the use of a technique that takes into account the risk to health of population exposed to the negative effects of pollutants released during the use of explosives. Based on the results presented in the work [38], the use of emulsion explosive of the Ukrainit-PP-2B type during underground mining operations reduces the release of harmful substances up to $38 \%$ and leads to a decrease in the inhibitory effect on agricultural cultures [39]. Therefore, in order to establish the expected level of ecological hazard, the coefficients and indexes of hazard should be compared, when using TNT-containing explosives - these are Ammonite No. $6 \mathrm{ZhV}$ and emulsion explosive Ukrainit-PP [40].

The coefficient of ecological hazard of the possible occurrence of non- carcinogenic effects in living organisms under the influence of the considered pollutants

$$
H Q_{i}=\frac{C_{i}}{R f C},
$$

where $C_{i}$ is the level of the $\mathrm{i}$-th substance influence, $\mathrm{mg} / \mathrm{m}^{3} ; R f C$ is safe influence level, $\mathrm{mg} / \mathrm{m}^{3}$.

The hazard index from the combined effects of environmentally hazardous substances

$$
H I=\Sigma H Q_{i} .
$$

The calculation results of the expected coefficients and indexes of hazard for the environmental objects when using the TNT-containing explosives - Ammonite No.6 ZhV and emulsion explosive Ukrainit-PP for the construction of the tunnel, are presented in Table 1.

Table 1. Calculation results of the expected coefficients and indexes of hazard.

\begin{tabular}{|l|c|c|c|c|c|}
\hline \multirow{2}{*}{ Indicator } & \multicolumn{5}{c|}{ The distance from the emission source, $\mathrm{m}$} \\
\cline { 2 - 6 } & 100 & 200 & 300 & 400 & 500 \\
\hline$H Q\left(\mathrm{NO}_{\mathrm{x}}\right)$ & 0.340 & 0.306 & 0.282 & 0.248 & 0.222 \\
\hline$H Q(\mathrm{CO})$ & 0.040 & 0.034 & 0.028 & 0.022 & 0.018 \\
\hline$H I$ & 0.380 & 0.340 & 0.310 & 0.270 & 0.240 \\
\hline \multicolumn{7}{|c|}{ Ukrainit-PP } \\
\hline$H Q\left(\mathrm{NO}_{\mathrm{x}}\right)$ & 0.204 & 0.184 & 0.169 & 0.149 & 0.133 \\
\hline$H Q(\mathrm{CO})$ & 0.024 & 0.020 & 0.017 & 0.013 & 0.011 \\
\hline$H I$ & 0.230 & 0.200 & 0.190 & 0.160 & 0.140 \\
\hline
\end{tabular}

According to the results of calculating the coefficients and indexes of hazard, a histogram of changes in the expected hazard indexes is constructed with a given distance from the source of emission (Fig. 7). 


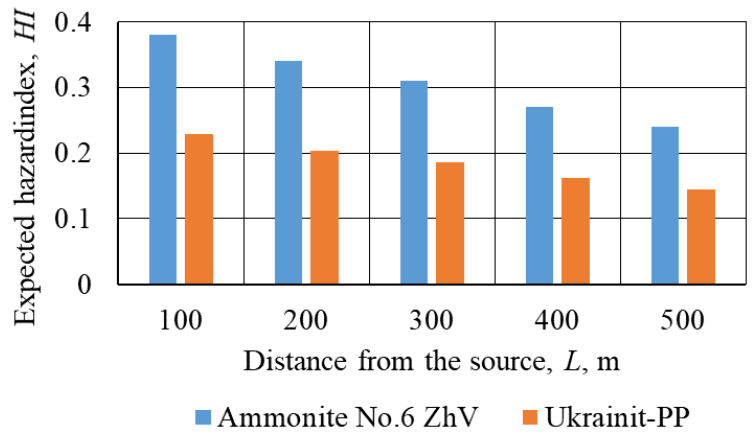

Fig. 7. The histogram of changes in the expected hazard index at a distance from the source of emission with the use of Ammonite No. $6 \mathrm{ZhV}$ and Ukrainit-PP.

It can be seen from the Fig. 7, that when using the emulsion explosive Ukrainit-PP, the expected hazard index compared to TNT-containing explosives Ammonite No. 6 ZhV decreases up to $60 \%$.

\section{Conclusions}

As a result of the development and implementation into production of a new DBO passport for conducting the tunnels in the city of Dnipro (Ukraine), the following disadvantages have been avoided and the following innovations have been received. The developed DBO passport is in compliance with NPAOP 0.00-1.66-13. The disposition of the blast-holes in the driving place corresponds to the ellipsoidal shape of the tunnels, and the cut area is considered when calculating the total number of blast-holes in the driving place. The type has been substantiated and simulation has been made of the applied cut. The total number of calculation formulas has been increased to 48 pcs., as well as minor deficiencies, errors and outdated data, presented in the old DBO passport, have been eliminated.

The following technical parameters have been improved. The number of chargeable blast-holes has decreased from 108 to 95 pcs. (by 13 pcs., 12\%). The number of uncharged blast-holes has decreased from 4 to 1 pc. (by 3 pcs., $75 \%$ ). The consumption of explosive has decreased from 75.5 to $66.5 \mathrm{~kg}$ (by $9 \mathrm{~kg}, 12 \%$ ). The number of used blasting caps has been reduced from 108 to 95 pcs. (by 13 pcs., 12\%). The number of electric detonators has decreased from 3 to 2 pcs. (by 1 pcs., 33\%). The length of the explosive charge has been reduced, which was determined without taking into account the length of the explosive cartridge for the cut blast holes from 0.75 to $0.45 \mathrm{~m}$ (by $0.3 \mathrm{~m}, 40 \%$ ) and for the outer blast holes - from 0.5 to $0.3 \mathrm{~m}$ (by $0.2 \mathrm{~m}, 40 \%$ ).

With an increase in the diameter of the blast-hole from 42 to $45 \mathrm{~mm}$, their number decreases from 95 to 84 pcs., and the consumption of explosive increases from 66.5 to $71.7 \mathrm{~kg}$. It has also been established, that when using the emulsion explosive Ukrainit-PP instead of the TNT- containing explosive Ammonite No. $6 \mathrm{ZhV}$, the hazard index is expected to decrease up to $60 \%$.

The authors express their gratitude to V.P. Kuprin, Doctor of Chemistry, Professor, Laureate of State Prize of Ukraine in science and technology, for providing the consultancy and organizational support in performing the computational simulation. 


\section{References}

1. Buzilo, V., Koshka, O., \& Yavors'kyy, A. (2011). Bolt-pneumatic support for development workings with big cross-section. Technical And Geoinformational Systems in Mining, 149-155. https://doi.org/10.1201/b11586-25

2. Hrinov, V., \& Khorolskyi, A. (2018). Improving the process of coal extraction based on the parameter optimization of mining equipment. E3S Web of Conferences, (60), 00017. https://doi.org/10.1051/e3sconf/20186000017

3. Vladyko, O., Kononenko, M., \& Khomenko, O. (2012). Imitating modeling stability of mine workings. Geomechanical Processes During Underground Mining - Proceedings of the School of Underground Mining, 147-150. https://doi.org/10.1201/b13157-26

4. Svetkina, O., Netiaga, O., \& Tarasova, H. (2015). Sorbents of purify mine waters. New Developments in Mining Engineering 2015: Theoretical and Practical Solutions of Mineral Resources Mining, 111-115. https://doi.org/10.1201/b19901-21

5. Sudakov, A., Dreus, A., Sudakova, D., \& Khamininch, O. (2018). The study of melting process of the new plugging material at thermomechanical isolation technology of permeable horizons of mine opening. E3S Web of Conferences, (60), 00027. https://doi.org/10.1051/e3sconf/20186000027

6. Stupnik, N., Kalinichenko, V., Pismennij, S., \& Kalinichenko, E. (2015). Features of underlying levels opening at "ArsellorMittal Kryvyi Rih" underground mine. New Developments in Mining Engineering 2015: Theoretical and Practical Solutions of Mineral Resources Mining, 39-44. https://doi.org/10.1201/b19901-8

7. Sudakov, A. Khomenko, O., Isakova, M., \& Sudakova, D. (2016). Concept of numerical experimentof isolation of absorptive horizons by thermoplastic materials. Naukovyi Visnyk Natsionalnoho Hirnychoho Universytetu, (5), 12-16.

8. Sudakov, A., Dreus, A., Khomenko, O., \& Sudakova, D. (2017). Analytical study of heat transfer in absorptive horizons of borehole at forming cryogenic protecting of the plugging material. Naukovyi Visnyk Natsionalnoho Hirnychoho Universytetu, (3), 38-42.

9. Golinko, V.I., Luts, I.O., \& Yavorskaya, Ye.A. (2012). Reserch of air and dust balance in inclined shaft of the mine N. 9-10 at manganese dressing plant. Naukovyi Visnyk Natsionalnoho Hirnychoho Universytetu, (3), 98-101.

10. Lozynskyi, V., Saik, P., Petlovanyi, M., Sai, K., \& Malanchuk, Y. (2018). Analytical Research of the Stress-Deformed State in the Rock Massif around Faulting. International Journal of Engineering Research in Africa, (35), 77-88. https://doi.org/10.4028/www.scientific.net/jera.35.77

11. Khomenko, O., Kononenko, M., \& Myronova, I. (2013). Blasting works technology to decrease an emission of harmful matters into the mine atmosphere. Mining of Mineral Deposits, 231-235. https://doi.org/10.1201/b16354-43

12. Brown, G.I. (1998). The Big Bang: A History of Explosives.

13. Kholodenko, T., Ustimenko, Y., Pidkamenna, L., \& Pavlychenko, A. (2014). Ecological safety of emulsion explosives use at mining enterprises. Progressive Technologies of Coal, Coalbed Methane, and Ores Mining, 255-260. https://doi.org/10.1201/b17547-45

14. Kholodenko, T., Ustimenko, Y., Pidkamenna, L., \& Pavlychenko, A. (2015). Technical, economic and environmental aspects of the use of emulsion explosives by ERA brand in underground and surface mining. New Developments in Mining Engineering 2015: Theoretical and Practical Solution of Mineral Resources Mining, 211-219. https://doi.org/10.1201/b19901-38

15. Gorova, A., Pavlychenko, A., \& Kholodenko, T. (2013). Prospects for the bioindication methods implementation in the environmental management system of industrial enterprises. Annual Scientific-Technical Collection - Mining of Mineral Deposits 2013, 83-84. https://doi.org/10.1201/b16354-16

16. Khomenko, O., Kononenko, M., Myronova, I., \& Sudakov, A. (2018). Increasing ecological safety during underground mining of iron-ore deposits. Naukovyi Visnyk Natsionalnoho Hirnychoho Universytetu, (2), 29-38. https://doi.org/10.29202/nvngu/2018-2/3 
17. Kutuzov, B.N., \& Andrievskiy, A.P. (2003). Novaya teoriya i novye tekhnologii razrusheniya gornykh porod udlinennymi zaryadami vzryvchatykh veshchestv.

18. Mertuszka, P., Cenian, B., Kramarczyk, B., \& Pytel, W. (2018). Influence of Explosive Charge Diameter on the Detonation Velocity Based on Emulinit 7L and 8L Bulk Emulsion Explosives. Central European Journal of Energetic Materials, 15(2), 351-363. https://doi.org/10.22211/cejem/78090

19. Mertuszka, P., \& Kramarczyk, B. (2018). The Impact of Time on the Detonation Capacity of Bulk Emulsion Explosives based on Emulinit 8L. Propellants, Explosives, Pyrotechnics, 43(8), 799804. https://doi.org/10.1002/prep.201800062

20. Gorinov, S.A., Kuprin, V.P., \& Kovalenko, I.L. (2009). Evaluation of the detonation ability emulsion explosives. High energy materials processing, 18-26.

21. Lyashenko, V., Vorob'ev, A., Nebohin, V., \& Vorob'ev, K. (2018). Improving the efficiency of blasting operations in mines with the help of emulsion explosives. Mining of Mineral Deposits, 12(1), 95-102. https://doi.org/10.15407/mining12.01.095

22. Sobolev, V., Ustimenko, Y., Nalisko, M., \& Kovalenko, I. (2018). The macrokinetics parameters of the hydrocarbons combustion in the numerical calculation of accidental explosions in mines. Naukovyi Visnyk Natsionalnoho Hirnychoho Universytetu, (1), 89-98. https://doi.org/10.29202/nvngu/2018-1/8

23. Kononenko, M., Khomenko, O., Sudakov, A., Drobot, S., \& Lkhagva, T. (2016). Numerical modelling of massif zonal structuring around underground working. Mining of Mineral Deposits, 10(3), 101-106. https://doi.org/10.15407/mining10.03.101

24. Pokrovsky, N.M. (1977). Underground structures and mines construction practices.

25. Andrievskiy, A.P., \& Avdeev, A.M. (2006). Metodika opredeleniya parametrov vzryvaniya pri ochistnoy dobyche i prokhodke gornykh vyrabotok. Izvestiya vysshikh uchebnykh zavedeniy. Gornyy zhurnal, (6), 60-65.

26. Onika S.G., \& Stasevich V.I. (2005). Razrushenie gornykh porod vzryvom.

27. Kononenko, M., \& Khomenko, O. (2010). Technology of support of workings near to extraction chambers. New Techniques and Technologies in Mining - Proceedings of the School of Underground Mining, 193-197. https://doi.org/10.1201/b11329-32

28. Dychkovskyi, R., Lozynskyi, V., Saik, P., Petlovanyi, M., Malanchuk, Y., \& R. Malanchuk, Z. (2018). Modeling of the disjunctive geological fault influence on the exploitation wells stability during underground coal gasification. Archives of Civil and Mechanical Engineering, 18(4), 1183-1197. https://doi.org/10.1016/j.acme.2018.01.012

29. Bondarenko, V., Kovalevs'ka, I., \& Fomychov, V. (2012). Features of carrying out experiment using finite-element methodat multivariate calculation of "mine massif - combined support" system. Geomechanical Processes during Underground Mining - Proceedings of the School of Underground Mining, 7-13. https://doi.org/10.1201/b13157-3

30. Stupnik, M., Kalinichenko, V., Pysmennyi, S., \& Kalinichenko, O. (2018). Determining the qualitative composition of the equivalent material for simulation of Kryvyi Rih iron ore basin rocks. Naukovyi Visnyk Natsionalnoho Hirnychoho Universytetu, (4), 21-27. https://doi.org/10.29202/nvngu/2018-4/4

31. Sobolev, V.V., Shiman, L.N., Nalisko, N.N., \& Kirichenko, A.L. (2017). Computational modeling in research of ignition mechanism of explosives by laser radiation. Naukovyi Visnyk Natsionalnoho Hirnychoho Universytetu, (6), 53-60.

32. Khomenko, O., Rudakov, D., \& Kononenko, M. (2011). Automation of drill and blast design. Technical and Geoinformational Systems in Mining, 271-275. https://doi.org/10.1201/b11586-45

33. Kononenko, M., Khomenko, O., Savchenko, M., \& Kovalenko, I. (2019). Method for calculation of drilling-and-blasting operations parameters for emulsion explosives. Mining of Mineral Deposits, 13(3), 22-30. https://doi.org/10.33271/mining13.03.022

34. Khomenko, O., Kononenko, M., \& Bilegsaikhan, J. (2018). Classification of Theories about Rock $\begin{array}{llll}\text { Pressure. Solid } & \text { State } & \text { Phenomena, } & \text { (277), }\end{array}$ https://doi.org/10.4028/www.scientific.net/ssp.277.157 
35. Babets, D. (2018). Rock Mass Strength Estimation Using Structural Factor Based on Statistical

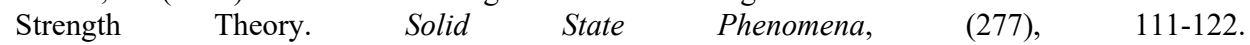
https://doi.org/10.4028/www.scientific.net/ssp.277.111

36. Khomenko, O., Kononenko, M., Kovalenko, I., \& Astafiev, D. (2018). Self-regulating roofbolting with the rock pressure energy use. E3S Web of Conferences, (60), 00009. https://doi.org/10.1051/e3sconf/20186000009

37. Mironova, I., \& Borysovs'ka, O. (2014). Defining the parameters of the atmospheric air for iron ore mines. Progressive Technologies of Coal, Coalbed Methane, and Ores Mining, 333-339. https://doi.org/10.1201/b17547-57

38. Khomenko, O., Kononenko, M., \& Myronova, I. (2017). Ecological and technological aspects of iron-ore underground mining. Mining of Mineral Deposits, 11(2), 59-67. https://doi.org/10.15407/mining11.02.059

39. Myronova, I. (2015). The level of atmospheric pollution around the iron-ore mine. New Developments in Mining Engineering 2015: Theoretical and Practical Solution of Mineral Resources Mining, 193-197. https://doi.org/10.1201/b19901-35

40. Fedko, M.B., Kolosov, V.A., Pismennyi, S.V. \& Kalinichenko, Ye.V. (2014). Economic aspects of change-over to TNT-free explosives for the purposes of ore underground mining in Kryvyi Rih basin. Naukovyi Visnyk Natsionalnoho Hirnychoho Universytetu, (4), 79-84. 